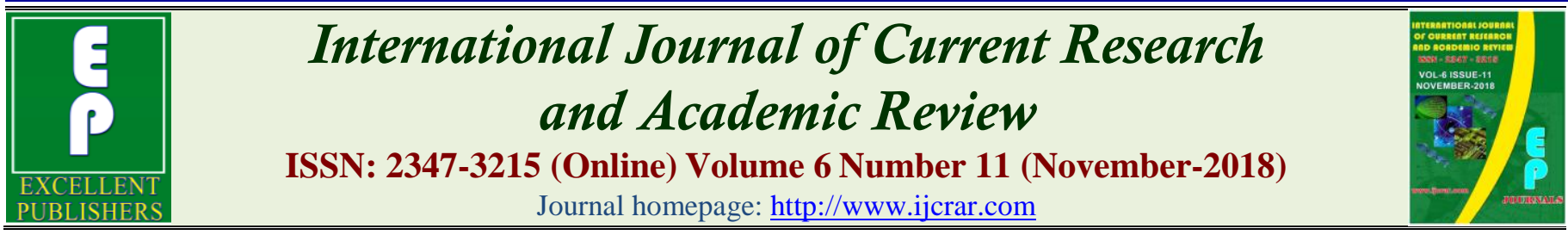

doi: https://doi.org/10.20546/ijcrar.2018.611.001

\title{
Technical Methodology for the Vehicle Maintenance Process under Quality Standards at a Chevrolet Dealership
}

\author{
Jose Luis Gavidia Garcia*, Ángel Rigoberto Guamán Mendoza, Richard Armando Caiza Castillo \\ and Eddy Stalin Alvarado Pacheco
}

\author{
${ }^{1}$ Ingeniero Industrial, Magister en Gestión Industrial y SistemasProductivos, Docente de la Escuela Superior \\ Politécnica de Chimborazo (2013-2018) Ecuador \\ ${ }^{2}$ Ingeniero Industrial, Magister en DocenciaUniversitaria e Investigación Educativa, Magister en Seguridad e \\ Higiene Industrial y Ambiental, Vice Decano de la Facultad de Mecánica ESPOCH, Docente de la Escuela Superior \\ Politécnica de Chimborazo - Ecuador \\ ${ }^{3}$ Licenciado en Sistemas, Magister en Educación virtual a Distancia, Docente de la Universidad Nacional de Loja \\ ${ }^{4}$ Ingeniero Industrial, Magister en Gestión Industrial y SistemasProductivos, Docente de la Universidad Estatal de \\ Bolivar (2016 - 2018) Ecuador
}

*Corresponding author

\begin{abstract}
The vehicle maintenance process carried out in the Chevrolet Dealer Network of the country is under the requirements and control of General Motor's (GM), who issues the guidelines in this field applying quality standards, with the mission of keeping satisfied customers and faithful to the brand, and the most important thing is not only to keep a vehicle in perfect condition, but also to safeguard the safety of the families that purchase a Chevrolet vehicle, unlike a common workshop, the qualified Chevrolet workshop is measured through the Index of Customer Satisfaction (CSI), which is a percentage indicator (\%) that measures the level of quality in the service, for which all Chevrolet dealers in the country compete, for this reason, this activity that belongs to the Post sale area must be governed by strict quality control, that is, having qualified technicians, who receive permanent training courses in various subject s, as well as all the people who belong to this area and have a direct relationship or contact with the client, in addition to providing an original spare parts service that meets a high quality standard. The concessionaire object of analysis has a C.S.I of $67.5 \%$, result of the survey made to the clients, this indicator is measured monthly.
\end{abstract}

\section{Article Info}

Accepted: 18 October 2018

Available Online: 20 November 2018

\section{Keywords \\ Vehicle maintenance, Process, Technician, Mechanic, After-sales, Concessionaire, Quality control, Customer.}

\section{Introduction}

The organizations are focused on offering their clients a quality service to stay in an increasingly competitive market, so they require that their processes, technical and administrative, among others, have the appropriate connections, continuous improvement is a fundamental entity for any organization, which apparently works well, is susceptible to improvement, it is beneficial to detect flaws and correct internally, before the client does so.

In the accelerated pace of growth of society, the car has become a necessity rather than a luxury, a very useful medium for the development of activities of various 
kinds. Each year the vehicle fleet increases a large number of vehicles that are acquired by public institutions, private and natural persons. GM Ecuador assembles on average 105 vehicles per day, to this we must increase the imports, both heavy and light.

https://dspace.ups.edu.ec/bitstream/123456789/1936/12/ UPS-CT002335.pdf

A Chevrolet dealer, through the post sale area, provides vehicle maintenance service focused on maintaining satisfied and loyal customers, offering quality work and guaranteed safety, has qualified workshops for this purpose, all Chevrolet dealers operate under the same scheme standardized by General Motor's (GM) using ISO 9001: 2015, the dealer selected for this study, maintains for the moment a Customer Satisfaction Index (CSI) of $67.5 \%$, the same as measured monthly, where The entire network of Chevrolet dealers in the country participates, the goal is to stay in the first places in the entire Network.

The most important aspect of preventive, predictive and corrective maintenance is to safeguard the safety of its occupants, in addition to guaranteeing optimum operating conditions and extending the useful life of the vehicle.

The process of standardized vehicle maintenance applied at a Chevrolet dealership is based on the following points.

Vehicle reception. - A service advisor attends to the client, welcomes him and welcomes the unit.

Work order. - The service advisor generates the work order, where the type of maintenance and other customer requirements are recorded.

Mechanical Technician - The vehicle enters the workshop to the bay of the technician assigned, who performs the respective maintenance.

Quality Control - The service adviser performs a quality control after maintenance to ensure that the customer's request has been made to satisfaction, when nonconformities are found, the unit is returned to the responsible technician, once the same is corrected, point four is repeated.

Washing of the Unit - All vehicles subject to maintenance are washed by courtesy of the dealer before delivery to the customer.
Box - Once the vehicle is ready for delivery, the customer cancels the box and removes the unit.

The company has a maintenance plan established by the brand, with its respective supports and formats with which the after-sales area adequately controls the information, this is resumes, checklist, work orders, warranty management, among others that facilitate the process, analysis and decision making for continuous improvement.

\section{Theoretical foundations}

\section{Maintenance}

Maintenance is defined as all actions that aim to maintain a good or machine in a state in which it can carry out its function in optimal conditions. These actions include the combination of technical and administrative areas such as the spare parts and accessories warehouse.

Within the vehicle maintenance we can highlight three basic types of maintenance, which are:

Predictive maintenance: When diagnoses or measurements are made that allow to predict if it is necessary to make corrections, adjustments or changes of spare parts and accessories before a fault occurs, for example, when warranty is covered.

Preventive maintenance: Consists of following the manufacturer's instructions, which are detailed in the vehicle manual by type of service and the time slots in which the maintenance operations must be carried out, following the maintenance plan established by the brand, which indicates every five a thousand kilometers of travel.

Corrective maintenance: The one in which the different parts of the vehicle are repaired when they stop working or start to fail, in many cases replacement of parts and accessories is required.

https://www.recope.go.cr/wpcontent/uploads/2012/11/FOLLETODSE.pdf

These aspects must be clearly defined when we try to determine the type of maintenance that should be applied.

Preventive maintenance is the most important, since it prevents the vehicle from unexpectedly failing, is the one 
intended for the conservation of the automotive by carrying out the revision, repair and replacement of spare parts and accessories that guarantee their good functioning and reliability, in addition, lengthen the useful life of the mobile and prevent unexpected failures.

In the design of the Maintenance Plan, two very important considerations that affect some equipment in particular must be taken into account. In the first place, some teams are subject to legal regulations that regulate their maintenance, forcing certain activities to be carried out with an established periodicity, for this case study is every five thousand kilometers.

Secondly, some of the maintenance activities can not be carried out without the specialized equipment, because it requires knowledge and / or specific means that are only in the hands of the manufacturer, distributor or a specialist in the team, hence the importance of a qualified workshop.

Some equipment is subject to regulations and regulations by the manufacturer, especially equipment that requires calibration and operational knowledge.

\section{Importance of maintenance}

Every vehicle, whether new or used, requires certain periodic routine maintenance tasks that guarantee its proper functioning in any condition.

As a result of normal use, there are components that wear out and stop performing their function optimally. The most complex and expensive usually have a long duration, while the simplest and most economical ones must be changed or revised every five thousand or ten thousand kilometers.

https://www.elcomercio.com/deportes/carburando/import ancia-mantenimiento.html.

\section{Materials and Methods}

The methodology for the development of this work consists of the following phases:

\section{Scientific method}

It allows for a set of procedures to guide research in a methodical and logical manner.

\section{Descriptive method}

This type of investigation allows to observe and describe the different processes of vehicle maintenance.

\section{Technical procedure}

1. Reception of the Unit: A service advisor welcomes the client, receives his vehicle and enters the office to make the work order in the system.

2. Work order: The service advisor prepares the work order by entering all the client's requirements into the system, for which a computer and a printer are required.

3. Carry out the maintenance: The mechanical technician receives the maintenance unit, which is detailed in the worksheet, for it carries out the following activities.

Inspection of the unit, to determine hidden damage to the naked eye.

Record in the worksheet any extra news detected.

Request for spare parts and accessory for the determined maintenance.

Perform the maintenance activity.

Quality inspection, to ensure proper maintenance.

The materials used for this activity are; an elevator, tools, pressurized air line, electrical source and a Tech, the same one that depends on the brand of the vehicle.

4. Quality audit: The service advisor performs a quality audit based on the type of maintenance and the requirements determined in the worksheet, as a result of which two results can be determined:

Unit No Ok. -When determining any non-compliance, the unit is returned to the responsible technician for correction, after which, a second quality audit is carried out.

Unit Ok. - If the unit is in satisfactory condition, it goes to the next washing process.

For the realization of this point a quality bay is required.

5. Washing of the unit: After proper maintenance, the vehicle is washed for later delivery to the customer. Among the materials used for this activity are: A washing machine for vehicles, drying accessories, a vacuum cleaner, and interior cleaning accessories. 


\section{Population and sample}

To determine the CSI, a number of respondents are considered among all the customers served by any type of maintenance, that is, among all the clients that have visited the dealership within a month to perform the maintenance of their vehicle, the Call Center performs a quality survey to determine this indicator.

The CSI consists of two measurement parameters, Q1 and Q2, however, other indicators such as Q4, Q8, Q11 and Q12 are used to determine the quality of service (Table 1).

Table.1 Quality of service indicators at the dealership

\begin{tabular}{|c|c|c|}
\hline \multicolumn{3}{|c|}{ ENCUESTA ONLINE SERVICIOS } \\
\hline \multicolumn{2}{|r|}{ Preguntas } & \\
\hline \multirow{2}{*}{\multicolumn{2}{|c|}{$\begin{array}{l}\text { ¿Recientemente realizó trabajos de reparación o } \\
\text { mantenimiento de su Chevrolet Modelo........... En nuestro } \\
\text { concesionario de la agencia.............concretamente el } \\
\text { día............. Eso es correcto? }\end{array}$}} & \\
\hline & & Puntaje \\
\hline$Q 1$ & $\begin{array}{l}\text { ¿Basándose en su experiencia de mantenimiento o } \\
\text { reparación de su vehículo, ¿cuál es su grado de } \\
\text { satisfacción con el concesionario? }\end{array}$ & $5 p$ \\
\hline$Q 12$ & $\begin{array}{l}\text { ¿Cuán satisfecho se encuentra con el trabajo realizado } \\
\text { en su vehículo? }\end{array}$ & $5 p$ \\
\hline Q11 & $\begin{array}{l}\text { Cuán satisfecho está usted con el agendamiento de } \\
\text { cita? }\end{array}$ & $5 p$ \\
\hline Q4 & $\begin{array}{l}\text { ¿Luáles su nivel de satistacción con la atención } \\
\text { recibida por parte de nuestro coordinadoritécnico de } \\
\text { caruicio? }\end{array}$ & $5 p$ \\
\hline Q8 & $\begin{array}{l}\text { ¿Su automóvil se entregó a la hora prometida y se le } \\
\text { explicó claramente los trabajos realizados? }\end{array}$ & si/no \\
\hline Q2 & $\begin{array}{l}\text { ¿Qué tan probable es que usted recomiende este } \\
\text { concesionario a sus familiares o amigos }\end{array}$ & $10 p$ \\
\hline
\end{tabular}

Made by: Gavidia J, 2018

Q1.- Refers to the question of satisfaction with the dealer, where the customer can give five different answers according to the CheckList (Table 3).

Table.2 Satisfaction Scale Q1

\begin{tabular}{|r|l|}
\hline \multicolumn{2}{|c|}{ Q1 } \\
\hline Grado & Escala de Satisfacción \\
\hline 1 & Totalmente Insatisfecho \\
\hline 2 & Poco Satisfecho \\
\hline 3 & Algo Satisfecho \\
\hline 4 & Muy Satisfecho \\
\hline 5 & Totalmente Satisfecho \\
\hline
\end{tabular}

Realizado por: Gavidia J, 2018
Q2 - It refers to the promoter question of recommendation to the concessionaire, to determine this indicator the following Formula is applied.

NPS $=$ PROMOTORES $(\%)-$ DETRACTORES $(\%)$

Donde:

NPS $=$ Net Promoting Value

Promoters $=$ Clients that evaluated with 9 and 10 on a scale of 0 to 10

Detractors $=$ Clients who evaluated $0-6$ on a scale of 0 to 10

Neutrals $=$ Clients who qualified with 7 and 8 on a scale of 0 to 10

The questions to be asked in the survey are determined in the CheckList (Table 3).

In every concessionaire the vehicle maintenance plan should be displayed as a visual administration, available to the client.

\section{Results and Discussions}

To determine the quality of service at the dealership and maintain customer loyalty by the brand, always based on continuous improvement, the CSI (\%) is calculated monthly.

The calculation by dealer is done with respect to the result of the survey carried out among all the customers who visited the dealer for the maintenance of their vehicle.

For the calculation we take a particular dealer, and we determine the value of the CSI for the month of September 2018, as detailed below.

Out of a total of 958 clients attended in the maintenance workshop, 52 surveys were conducted Online, resulting in $5.43 \%$.

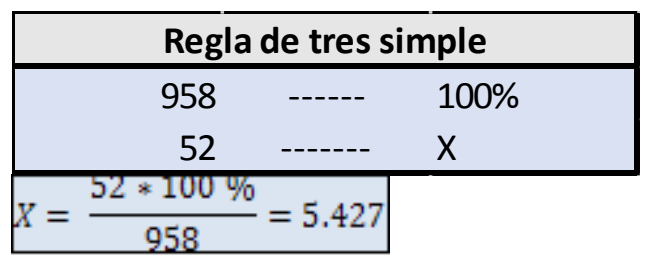

From a base of 431 Clients, the Net Promoter Value (NPS) is calculated 
From a base of 431 clients, 20 Detractors were determined, resulting in $4.64 \%$.

Detractors $=4.64 \%$

From a base of 431 clients, 387 Promoters were determined, resulting in $89.79 \%$.

Promoters $=89.79 \%$

From a base of 431 clients, 25 Neutrals were determined, resulting in $5.80 \%$.
Neutrals $=5.80 \%$

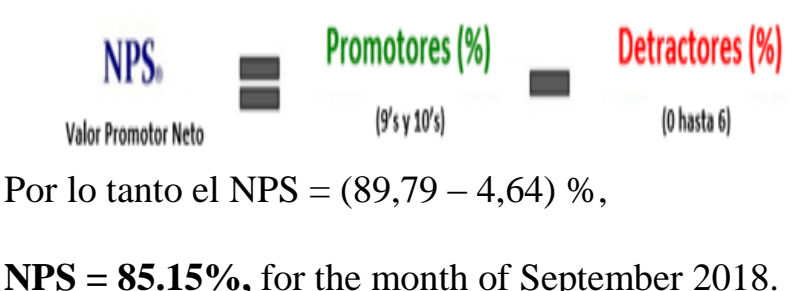

NPS $=\mathbf{8 5 . 1 5 \%}$, for the month of September 2018 .

Graph.1 Types of maintenance

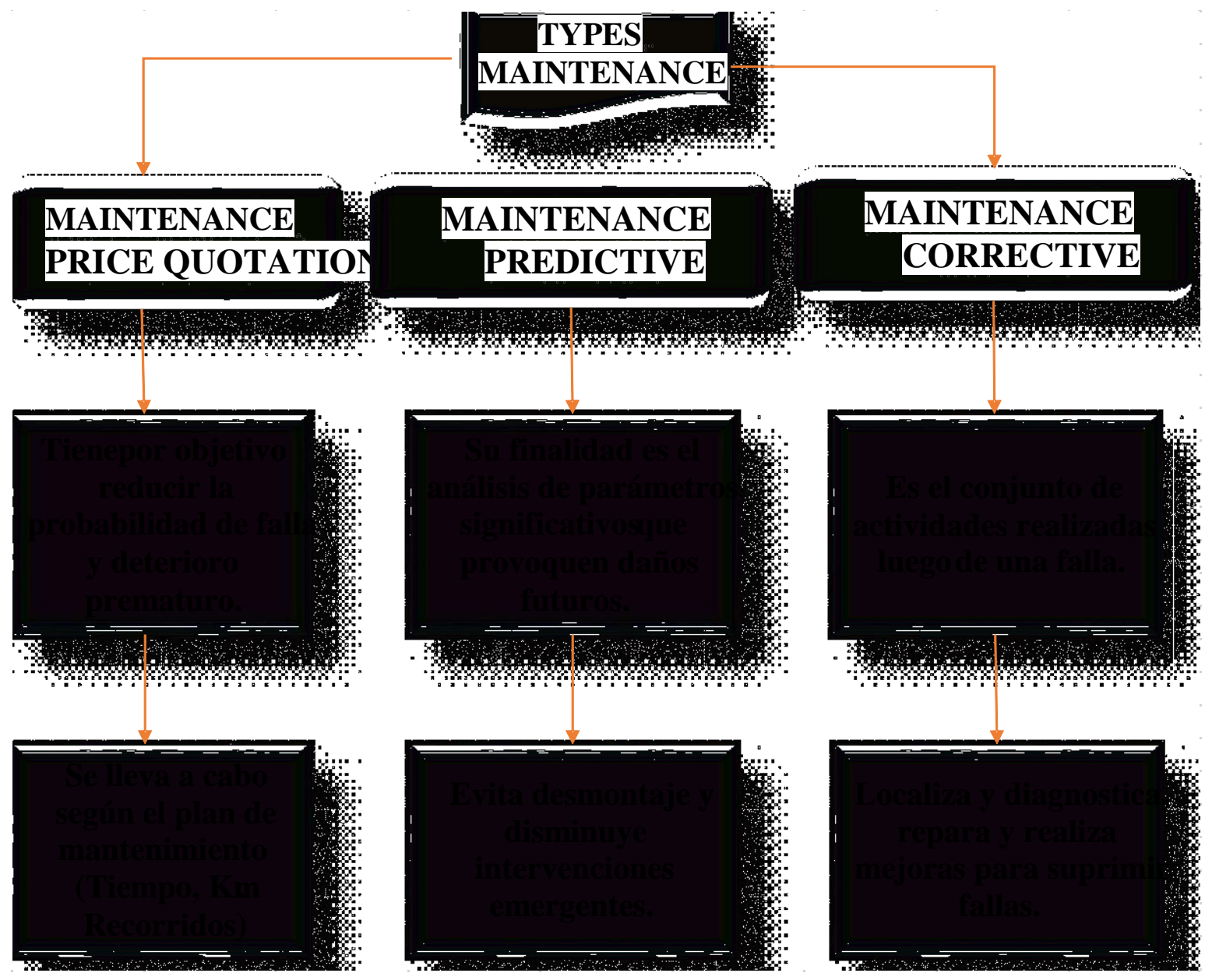

Made by: Gavidia J, 2018

Graph.2 Promoters and Detractors 


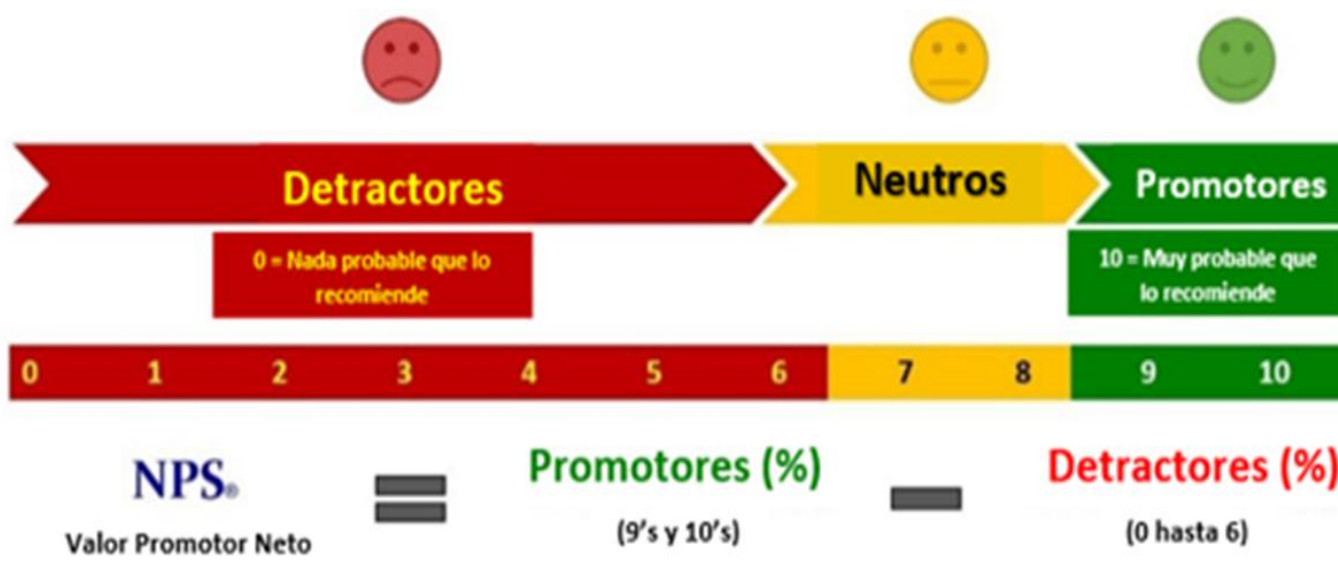

Made by: Gavidia J, 2018

Table.3 Questions for the quality of service survey

\begin{tabular}{|c|c|c|c|c|c|c|c|c|c|c|c|}
\hline \multicolumn{12}{|c|}{ CHECK LIST } \\
\hline \multicolumn{12}{|c|}{ PREGUNTAS PARA DETERMINAR LA CALIDAD DE SERVICIO EN EL CONCESIONARIO } \\
\hline Item & $\begin{array}{l}\text { En una escala del } 1 \text { al } 5 \text {, donde } 1 \text { es totalmente insatisfecho y } \\
5 \text { totalmente satisfecho. }\end{array}$ & \multicolumn{2}{|c|}{1} & \multicolumn{2}{|c|}{2} & \multicolumn{2}{|c|}{3} & \multicolumn{2}{|c|}{4} & \multicolumn{2}{|c|}{5} \\
\hline 1 & $\begin{array}{l}\text { ¿Cuál es su grado de satisfacción con la atención por parte del } \\
\text { Asesor de Servicio? }\end{array}$ & & & & & & & & & & \\
\hline 2 & ¿Cuál es el grado de saatisfacción con el mantenimiento realizado? & & & & & & & & & & \\
\hline \multirow[t]{2}{*}{3} & $\begin{array}{l}\text { ¿Cual es su grado de satisfacción con las instalaciones del } \\
\text { concesionario? }\end{array}$ & & & & & & & & & & \\
\hline & Por favor responder SI o NO a las siguiente preguntas & \multicolumn{5}{|c|}{ SI } & \multicolumn{5}{|c|}{ NO } \\
\hline 4 & Todos sus requerimientos fueron resueltos? & & & & & & & & & & \\
\hline 5 & Le mantuvieron informado sobre el mantenimiento de su vehículo? & & & & & & & & & & \\
\hline 6 & Le entregaros su vehículo a la hora acordada? & & & & & & & & & & \\
\hline 7 & $\begin{array}{l}\text { Le entregaron los repuestos cambiados, producto del } \\
\text { mantenimiento? }\end{array}$ & & & & & & & & & & \\
\hline 8 & Le informaron sobre el costo del mantenimiento a realizarse? & & & & & & & & & & \\
\hline \multirow[t]{2}{*}{9} & Le entregaron lavado se vehículo? & & & & & & & & & & \\
\hline & $\begin{array}{l}\text { En una escala del } 0 \text { al 10, por favor responda las siguiente } \\
\text { pregunta }\end{array}$ & 1 & 2 & 3 & 4 & 5 & 6 & 7 & 8 & 9 & 10 \\
\hline 10 & Recomendaría este concesionario a sus familiare y amigos? & & & & & & & & & & \\
\hline
\end{tabular}

Made by: Gavidia J, 2018

Table.4 Vehicle Maintenance Plan for one hundred thousand kilometers 


\begin{tabular}{|c|c|c|c|c|c|c|c|c|c|c|c|c|c|c|c|c|c|c|c|c|c|c|}
\hline & Operaciones de Servicio Km (x 1.000) & UNI & 5 & 10 & 15 & 20 & 25 & 30 & 35 & 40 & 45 & 50 & 55 & 60 & 65 & 70 & 75 & 80 & 85 & 90 & 95 & 100 \\
\hline & Cambio de filtro, acete de motor y revision de $18 \mathrm{P}$ & Minu & $\mathrm{R}$ & $\mathrm{R}$ & $\mathrm{R}$ & $\mathrm{R}$ & $\mathrm{R}$ & $\mathrm{R}$ & $\mathrm{R}$ & $\mathrm{R}$ & $\mathrm{R}$ & $\mathrm{R}$ & $\mathrm{R}$ & $\mathrm{R}$ & $\mathrm{R}$ & $\mathrm{R}$ & $\mathrm{R}$ & $\mathrm{R}$ & $\mathrm{R}$ & $\mathrm{R}$ & $\mathrm{R}$ & $\mathrm{R}$ \\
\hline & Canbio de filtro de combustible Primario & Minu & & $\mathrm{R}$ & & $\mathrm{R}$ & & $\mathrm{R}$ & & $\mathrm{R}$ & & $\mathrm{R}$ & & $\mathrm{R}$ & & $\mathrm{R}$ & & $\mathrm{R}$ & & $\mathrm{R}$ & & $\mathrm{R}$ \\
\hline & Canbio de filtro de combustible Secundario & Minu & & & & $\mathrm{R}$ & & & & $\mathrm{R}$ & & & & $R$ & & & & $\mathrm{R}$ & & & & $\mathrm{R}$ \\
\hline & Limpieza del tanque de combustible & Minu & & & & & & & & & & 1 & & & & & & & & & & 1 \\
\hline & Cambio de aceite caja de cambios & Minu & & & & $\mathrm{R}$ & & & & $\mathrm{R}$ & & & & $\mathrm{R}$ & & & & $\mathrm{R}$ & & & & $\mathrm{R}$ \\
\hline & Cambio aceite de diferencial & Minu & & & & $\mathrm{R}$ & & & & $\mathrm{R}$ & & & & $R$ & & & & $\mathrm{R}$ & & & & $\mathrm{R}$ \\
\hline & Cambio de aceite de la direccion hidraulica & Minu & & & & & & & & & & & & $\mathrm{I}$ & & & & & & & & 1 \\
\hline & Liquido sistema de enbraque & Minu & & & & & & & & & & & & 1 & & & & & & & & \\
\hline & Cojinete central del eje trasero & Minu & $\mathrm{L}$ & $\mathrm{L}$ & $\mathrm{L}$ & $\mathrm{L}$ & $\mathrm{L}$ & $\mathrm{L}$ & $\mathrm{L}$ & $\mathrm{L}$ & $\mathrm{L}$ & $\mathrm{L}$ & $\mathrm{L}$ & $\mathrm{L}$ & $\mathrm{L}$ & $\mathrm{L}$ & $\mathrm{L}$ & $\mathrm{L}$ & $\mathrm{L}$ & $\mathrm{L}$ & $\mathrm{L}$ & $\mathrm{L}$ \\
\hline & Grasa cubos de rueda (delanteros y traseros) & Minu & & & & & & & & $\mathrm{L}$ & & & & & & & & $\mathrm{L}$ & & & & \\
\hline & Zapatas de freno & Minu & & & & $\mathrm{R}$ & & & & $\mathrm{R}$ & & & & R & & & & $\mathrm{R}$ & & & & $\mathrm{R}$ \\
\hline & Grasa Crucetas y balineras de cardanes & Minu & $\mathrm{L}$ & $\mathrm{L}$ & $\mathrm{L}$ & $\mathrm{L}$ & $\mathrm{L}$ & $\mathrm{L}$ & $\mathrm{L}$ & $\mathrm{L}$ & $\mathrm{L}$ & $\mathrm{L}$ & $L$ & $\mathrm{~L}$ & $\mathrm{~L}$ & $\mathrm{~L}$ & $\mathrm{~L}$ & $\mathrm{~L}$ & $\mathrm{~L}$ & $\mathrm{~L}$ & $\mathrm{~L}$ & $\mathrm{~L}$ \\
\hline & Holgura de Valvulas & Minu & & $\mathrm{R}$ & & & & & & $\mathrm{R}$ & & & & & & & & $\mathrm{R}$ & & & & \\
\hline & Elemento de filtro de Aire* & Minu & & $\mathrm{R}$ & & $\mathrm{R}$ & & $\mathrm{R}$ & & $\mathrm{R}$ & & $\mathrm{R}$ & & $\mathrm{R}$ & & $\mathrm{R}$ & & $\mathrm{R}$ & & $\mathrm{R}$ & & $\mathrm{R}$ \\
\hline & Elemento de filtro de Aire Secundario* & Minu & & & & $\mathrm{R}$ & & & & $\mathrm{R}$ & & & & $\mathrm{R}$ & & & & $\mathrm{R}$ & & & & $\mathrm{R}$ \\
\hline & Refrigerante del motor ** & Minu & & & & & & & & & & & & & & & & $\mathrm{R}$ & & & & \\
\hline & Tuercas pernos en U (grapas ballestas) ${ }^{* * *}$ & Minu & $L$ & & & $\mathrm{~L}$ & & & & $\mathrm{~L}$ & & & & $\mathrm{~L}$ & & & & $\mathrm{~L}$ & & & & $\mathrm{~L}$ \\
\hline & Hojas de ballestas (alineacion, fisuras y deformaciones) & Minu & & & & $\mathrm{L}$ & & & & $\mathrm{L}$ & & & & $\mathrm{L}$ & & & & $\mathrm{L}$ & & & & $\mathrm{L}$ \\
\hline & Alineacion de direccion & Minu & & & & $\mathrm{R}$ & & & & $\mathrm{R}$ & & & & $R$ & & & & $\mathrm{R}$ & & & & $\mathrm{R}$ \\
\hline & Carrera y juego Ibre del pedal de freno & Minu & 1 & $\mathrm{I}$ & 1 & 1 & $\mathrm{I}$ & 1 & $\mathrm{I}$ & 1 & 1 & 1 & 1 & $\mathrm{I}$ & $\mathrm{I}$ & 1 & 1 & 1 & 1 & 1 & 1 & 1 \\
\hline & Pernos columna de direccion & Minu & & & & 1 & & & & 1 & & & & 1 & & & & 1 & & & & 1 \\
\hline & Electrolito baterias y rotacion & Minu & & 1 & & 1 & & 1 & & 1 & & 1 & & 1 & & 1 & & 1 & & 1 & & 1 \\
\hline & Estado de los bombillos & Minu & 1 & 1 & 1 & 1 & 1 & 1 & 1 & 1 & 1 & 1 & 1 & 1 & 1 & 1 & 1 & 1 & 1 & I & 1 & 1 \\
\hline & Regular perno tope freno motor & Minu & & & & 1 & & & & 1 & & & & 1 & & & & 1 & & & & 1 \\
\hline & Limpieza / Purga sistema neumatico & Minu & 1 & 1 & 1 & 1 & 1 & 1 & 1 & 1 & 1 & 1 & 1 & 1 & 1 & 1 & 1 & 1 & 1 & 1 & 1 & 1 \\
\hline & & & & & & & & & & & & & & & & & & & & & & \\
\hline & $\begin{array}{l}\text { "Bajo condiciones extremas se debe aumentar al } \\
\text { "O cada } 18 \text { meses } \\
{ }^{* * *} \text { Reducir periodo para Volquetas }\end{array}$ & 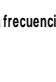 & & 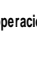 & & & & & & & & & & & & & & & & & & \\
\hline $\begin{array}{l}\mathrm{R}= \\
\mathrm{V}= \\
\mathrm{L}=\end{array}$ & $\begin{array}{l}\text { Reemplazo } \\
\text { Inspección y'o limpieza } \\
\text { Lubricacion }\end{array}$ & & & & & & & & & & & & & & & & & & & & & \\
\hline
\end{tabular}

Made by: Gavidia J, 2018

Table.5 CSI ranking of dealerships nationwide

\begin{tabular}{|c|c|c|c|c|c|c|c|c|c|}
\hline $\mathbf{N}^{\circ}$ & $\begin{array}{l}\text { RANKINGCONCESIONARIOS } \\
\text { VALORPROMOTORNETO(3M } \\
\text { ESES) (\% PROMOTORES- }\end{array}$ & mar-18 & abr-18 & may-18 & jun-18 & jul-18 & ago-18 & sep-18 & $\begin{array}{l}\text { Evolutio } \\
\text { n }\end{array}$ \\
\hline 3 & VALLEJOARAUJOGYE & $59,6 \%$ & $56,7 \%$ & $54,8 \%$ & $49,4 \%$ & $53,3 \%$ & $59,0 \%$ & $70,2 \%$ & 牙 \\
\hline 2 & CENTRAL CAR & $78,3 \%$ & $81,5 \%$ & $73,7 \%$ & $76,9 \%$ & $76,9 \%$ & $83,3 \%$ & $69,2 \%$ & $\sqrt{y}$ \\
\hline 7 & ASSA & $62,3 \%$ & $61,0 \%$ & $65,2 \%$ & $70,7 \%$ & $71,1 \%$ & $75,8 \%$ & $67,5 \%$ & $\sqrt{y}$ \\
\hline 5 & VALLEJO ARAUJO UIO & $41,0 \%$ & $39,7 \%$ & $48,8 \%$ & $52,6 \%$ & $56,6 \%$ & $60,7 \%$ & $67,3 \%$ & A \\
\hline 8 & IMBAUTO & $75,8 \%$ & $77,6 \%$ & $74,6 \%$ & $72,5 \%$ & $73,0 \%$ & $82,3 \%$ & $64,6 \%$ & $\sqrt{y}$ \\
\hline 6 & AUTOMOTORES CONTINENTAL & $63,3 \%$ & $64,4 \%$ & $66,4 \%$ & $66,1 \%$ & $67,7 \%$ & $61,1 \%$ & $64,0 \%$ & A \\
\hline 1 & VALLEJO ARAUJO MAN & $75,9 \%$ & $74,6 \%$ & $66,7 \%$ & $69,8 \%$ & $69,1 \%$ & $73,3 \%$ & $61,1 \%$ & $\sqrt{y}$ \\
\hline 9 & AUTOLASA & $51,8 \%$ & $51,6 \%$ & $49,7 \%$ & $55,1 \%$ & $54,5 \%$ & $54,3 \%$ & $58,9 \%$ & 舟 \\
\hline 10 & AUTOLANDIA & $68,7 \%$ & $70,1 \%$ & $61,3 \%$ & $56,3 \%$ & $53,1 \%$ & $57,7 \%$ & $58,0 \%$ & 4 \\
\hline 11 & LAVCA & $58,2 \%$ & $59,5 \%$ & $54,1 \%$ & $50,0 \%$ & $50,0 \%$ & $57,8 \%$ & $55,8 \%$ & $\sqrt{y}$ \\
\hline 12 & PROAUTO & $32,4 \%$ & $35,9 \%$ & $44,2 \%$ & $53,3 \%$ & $50,0 \%$ & $40,3 \%$ & $53,7 \%$ & 舟 \\
\hline 13 & INDUAUTO & $61,6 \%$ & $61,8 \%$ & $69,7 \%$ & $71,2 \%$ & $70,9 \%$ & $61,1 \%$ & $52,7 \%$ & $\sqrt{y}$ \\
\hline 4 & ECUAAUTO & $47,4 \%$ & $47,6 \%$ & $45,5 \%$ & $45,3 \%$ & $43,8 \%$ & $46,3 \%$ & $50,8 \%$ & 舟 \\
\hline 15 & AUTOMOTORES CONTINENTAL & $50,9 \%$ & $51,7 \%$ & $51,4 \%$ & $55,1 \%$ & $55,8 \%$ & $61,1 \%$ & $46,2 \%$ & $\sqrt{y}$ \\
\hline 14 & METROCAR ZONA 3 & $41,9 \%$ & $41,0 \%$ & $44,1 \%$ & $50,8 \%$ & $56,9 \%$ & $57,1 \%$ & $45,3 \%$ & $\sqrt{y}$ \\
\hline 16 & MIRASOL S.A. & $45,4 \%$ & $44,8 \%$ & $48,2 \%$ & $47,7 \%$ & $49,0 \%$ & $53,3 \%$ & $43,4 \%$ & $\sqrt{y}$ \\
\hline 19 & EMAULME & $39,7 \%$ & $38,8 \%$ & $34,4 \%$ & $40,2 \%$ & $43,3 \%$ & $35,8 \%$ & $36,7 \%$ & 皮 \\
\hline 17 & METROCAR NACIONAL & $30,1 \%$ & $29,4 \%$ & $37,2 \%$ & $42,7 \%$ & $45,1 \%$ & $46,3 \%$ & $33,3 \%$ & $\sqrt{y}$ \\
\hline 18 & METROCAR ZONA 1 & $25,0 \%$ & $24,3 \%$ & $34,9 \%$ & $39,8 \%$ & $40,9 \%$ & $41,3 \%$ & $27,8 \%$ & $\sqrt{y}$ \\
\hline
\end{tabular}

Made by: Gavidia J, 2018 
Graph.3 Data of NPS, CSI and PQR in the month of September 2018

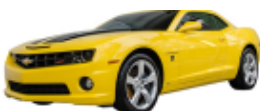

BaseTotal

$958^{52}$

2818-Sept.

$$
\begin{gathered}
\text { (2) Detractores } \\
20 \\
4,64 \%
\end{gathered}
$$

NPS NetPromotorScore

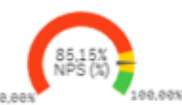

2818-Sept.

혈 BaseTotal

$\curvearrowright$ Contactados

- Cont.Efectivos Online 52

\section{CONTACTABILIDAD} basenps oncine (x) 431

$5,43 \%$
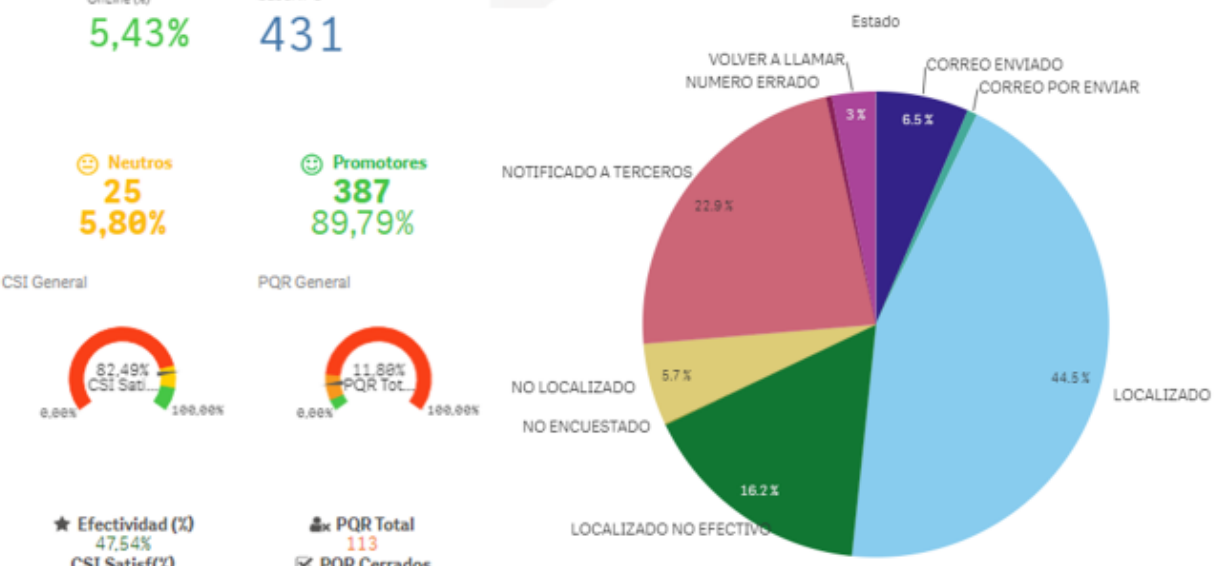

$$
\begin{gathered}
\text { 2x PQR Total } \\
113 \\
\text { \& PQR Cerrados } \\
6 \\
\text { - PQR Cerrado( }(\mathrm{x}) \\
5.31 \% \\
\text { 8.10\% }
\end{gathered}
$$$$
11,80 \mathrm{X}
$$$$
\text { OnLine ( } 7 \text { ( })
$$

ContactabilidadCont
$88.10 \%$

Made by: Gavidia J, 2018

Graph.4 Calculation methodology CSI - NPS based on QI and Q2

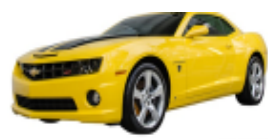

CSI NPS SERVICIOS

\section{METODOLOGIAS DE CALCULO}

PREGUNTA PROMOTORA DE RECOMENDACIÓN AL CONCESIONARIO Q2

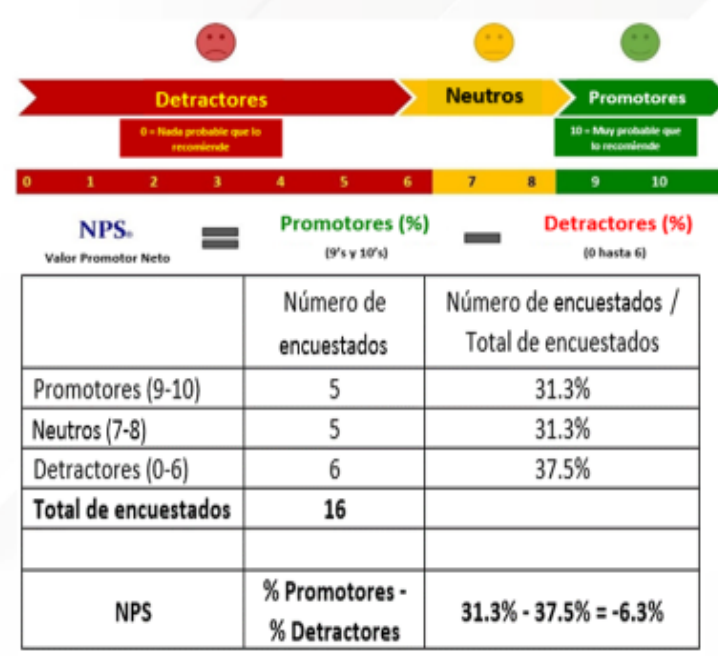

PREGUNTA DE SATISFACCION CON EL CONCESIONARIO Q1

\begin{tabular}{|l|c|c|c|}
\hline Escala de Satisfaçäo & $\begin{array}{c}\text { Número de } \\
\text { repuestas de los } \\
\text { clientes }\end{array}$ & $\begin{array}{c}\text { Valor da } \\
\text { respuesta }\end{array}$ & $\begin{array}{c}\text { Valor Total da Respuesta = } \\
\text { (Número de respuestas de los } \\
\text { clients }{ }^{*} \text { Valor da respuesta) }\end{array}$ \\
\hline Totalmente insatisfecho & 5 & 0 & 0 \\
\hline Poco satisfecho & 10 & 25 & 250 \\
\hline Algo satisfecho & 20 & 50 & 1,000 \\
\hline Muy satisfecho & 40 & 75 & 3,000 \\
\hline Totalmente satisfecho & 60 & 100 & 6,000 \\
\hline Totals & 135 & & 10,250 \\
\hline \multicolumn{4}{|c|}{ Promedio (Valor Total de la respuesta / Número Total de respuestas de los Clients) } \\
$10,250 / 135$ \\
$=75.93$
\end{tabular}

Made by: Gavidia J, 2018 
Graph.5 Percentage of contactability per agency

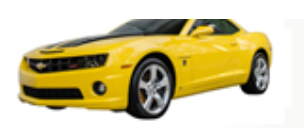

CONTACTABILIDAD POR AGENCIA

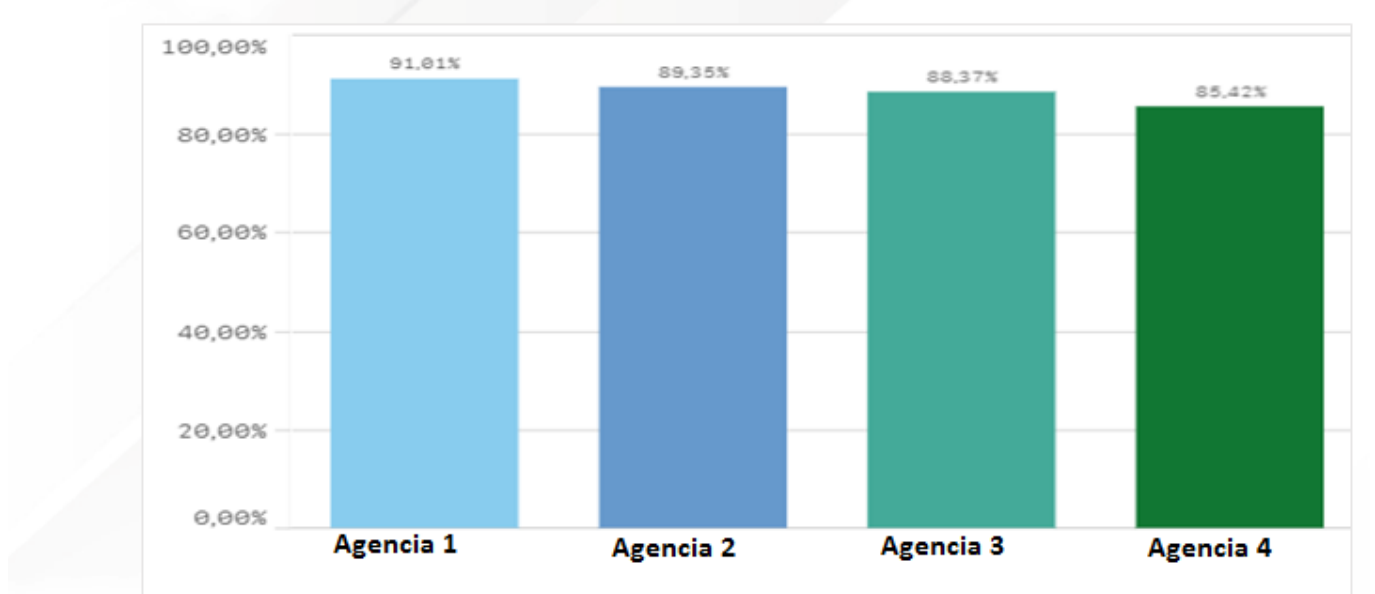

As in any company there will always be opportunities for improvement, which are the Problems Reported by the Client, for our study we will call it PQR.

For this dealer in this month reports a PQR of $11.80 \%$.

In this way for this particular concessionaire in the month of September it reports an NPS of $85.15 \%$, a CSI of $82.49 \%$, and a PQR of $11.80 \%$, as shown in the following graph.

In the following graph you can see the calculation methodology for the CSI and NPS, based on Q1 and Q2, in the month of September 2018.

Para un concesionario que tenga mas de una sucursal, se debe calcular estos indicadores por agencia y luego un general del concesionario, para nuestro caso en particular, el concesionario cuenta con cuatro agencias, como se muestra a continuación.

In this way a general CSI of the concessionaire is determined, taking possession of a position in table 4 at the national level, where the green and red arrow indicates the upward and downward respectively, depending on the value obtained in the previous month with respect to the current one.
It should be noted that the value of the CSI that is located in table 5 by dealer at the national level is the average of the last three months, because the brand provides economic incentives and benefits to the concessionaire that obtains this value over the determined objective during three Consecutive months.

In this way, if we take a random dealer (ASSA), we observe an average CSI for September of $67.5 \%$ at low, since in the previous month it obtained a value higher than $75.8 \%$.

\section{Conclusions}

- We can see m e Diante e 1 a $n$ to 1 i sisdelas i tua $\mathrm{c}$ ion ac tuald and dealers nationwide, none exceeds $75 \%$ of CSI, so it can be concluded that there are opportunities for improvement in the quality of service in the after sale area.

- In the activity of automotive maintenance, not all customers are satisfied with the service obtained, so some complain about poor service to what we know as $\mathrm{PQR}$, and this makes us lower our CSI service quality.

- Although the technical and administrative staff receive training is not reflected in the result of the CSI this year.

- It should be noted that the present process of automotive maintenance at the dealership is regulated and standardized for the entire network of Chevrolet dealers in the country. 
- The $\mathrm{S}$ is t e madeG e st i ng $\mathrm{d} \mathrm{eC}$ to $\mathrm{li} \mathrm{d}$ a $\mathrm{d}$ a $\mathrm{pl}$ ic to do at dealerships $\mathrm{p}$ and rmited $\mathrm{e} 1 \mathrm{i} \mathrm{m} \mathrm{i}$ tarlapol $\mathrm{t} \mathrm{t} \mathrm{i} \mathrm{c} \mathrm{ade} \mathrm{ca} 1$ $\mathrm{i} \mathrm{d}$ to ddela or $\mathrm{r} \mathrm{g}$ to or $\mathrm{z} \mathrm{c}$ i or $\mathrm{n} \mathrm{c}$ onla cor a $\mathrm{l}$ e stan $\mathrm{b}$ a s a d ostodoslosproc and sosn e ce $s$ to rivers $p$ to $r$ to $\mathrm{c}$ or $\mathrm{r}$ ec $\mathrm{t}$ e je $\mathrm{c} \mathrm{u} \mathrm{c}$ ion $\mathrm{d}$ and $\mathrm{l} \mathrm{m}$ to ntenim $\mathrm{i}$ e nto of $\mathrm{V}$ e hicles Chevrolet.

\section{Recommendations}

- A lno obtain over $75 \%$ CSI, it must work with the personnel performing the maintenance and persons have direct relationship with the customer, they are i ndisp e ns to $\mathrm{d}$ bles and ntro one $\mathrm{S}$ is $\mathrm{t}$ and $\mathrm{ma} \mathrm{G}$ e st i ng deC to $\mathrm{l}$ $\mathrm{i} \mathrm{d}$ to $\mathrm{d}$ e $\mathrm{nf} \mathrm{c}$ to do and $\mathrm{n} \mathrm{s}$ a $\mathrm{t} i \mathrm{n}$ to dc ion $\mathrm{c} l$ iand nte.

- E 1 Call Center must be a qualified staff with extensive knowledge of automotive maintenance activities, so you can make clear questions and avoid confusion customer because it can result in a low evaluation.

\section{References}

"https://dspace.ups.edu.ec/bitstream/123456789/1936/12/ UPS-CT002335.pdf" https://dspace.ups.edu.ec/bitstream/123456789/1 936/12/UPS-CT002335.pdf

"https://www.aec.es/web/guest/centroconocimiento/mantenimiento" https://www.aec.es/web/guest/centroconocimiento/mantenimiento "https://www.elcomercio.com/deportes/carburando/impo rtancia-mantenimiento.html" https://www.elcomercio.com/deportes/carburand o/importancia-mantenimiento.html.

"https://www.recope.go.cr/wpcontent/uploads/2012/11/FOLLETODSE.pdf" https://www.recope.go.cr/wpcontent/uploads/2012/11/FOLLETODSE.pdf

Arias - Paz (2001). Manual de Automóviles 54 ava. Edición.

Grupo Editorial Ceac S.A. (2003). Manual del Automóvil. Barcelona. Editorial Ceac. S.A.

José M Navarro, Tomás G Morales, José L García, Eduardo A Casado and Joaquín G García. (2010). Transporte y Mantenimiento de Vehículos. Madrid. 5ta. Edición. Paraninfo S.A.

Jose M Pérez (2003). Mecánica del Automóvil. Madrid. 10 ma. Edición. Paraninfo S.A.

Nicolás Rondón (2012). Miller Manual de Reparación de Automóviles. España.

Nilcer Gutierrez (2006). Mecánica Automotriz. Lima. Editora Palomino E.I.R.L.

Pablo Luque, Daniel Álvarez and Carlos Vera. (2012). Ingeniería del Automóvil. Madrid. Ediciones Paraninfo S.A.

Rodríguez Emilio, Bonet Carlos, Pérez Liyen. (2013). Propuesta de sistema de mantenimiento a los vehículos de transporte urbano y agrícola de una base de transporte de carga.Revista Ciencias Técnicas Agropecuarias. Vol 22. Número 2.

\section{How to cite this article:}

José Luis GavidiaGarcía, Ángel Rigoberto Guamán Mendoza, Richard Armando Caiza Castillo and Eddy Stalin Alvarado Pacheco. 2018. Technical Methodology for the Vehicle Maintenance Process under Quality Standards at a Chevrolet Dealership. Int.J.Curr.Res.Aca.Rev. 6(11), 1-10.

doi: https://doi.org/10.20546/ijcrar.2018.611.001 